\title{
The contribution of technology in business growth: the case of Greek ladies
}

Angelina Michaelidis Vassilakopoulou

Correspondence:

angelinamich@gmail.com TOGME/EEDE, Hellenic Management

Association, Athens, Greece

\section{Springer}

\begin{abstract}
The overall image of the use of digital technology by Greek women is not that encouraging. In information communication technology companies in the Greek market, there are only few ladies in high management mainly related to HR and marketing functions. The statistics on internet use show that although its penetration to the population is growing rapidly, there is a steady $10 \%$ gap between men (55\%) and women (45\%) use. It also becomes obvious, in relevant market surveys, that the internet is commercially underutilized in Greece, in comparison with the European average. Greece, in financial crisis, should leverage on technology in order to support financial development. However, there are few brilliant examples of Greek business ladies who have developed their businesses 'online'. Using digital media, social networks, applications, etc., they managed to break language and geographical barriers and set up their own micro-operations, responding to customer requests in the broader area or even globally. One could also find some interesting business examples from other European countries, from distant or dispersed areas. These micro-businesses cover multiple market industries even non-conventional ones such as e-tailing, publishing, energy consumption, specialized handcrafted goods. Here, we refer to hints and tips of the micro-business owners that led them to success over the internet and its potential impact on business growth. Moreover, since ladies in business usually have multiple roles to balance effectively in their lives, we will examine the impact of the systematic use of digital technology in work-life balance. In fact, the working population can save some time using digital technology to cover multiple needs. This may affect the working time zones, communication with family members, relationships to friends access to services, and the possibility to reserve some valuable 'quality time' for the lady entrepreneur. Having that available, women entrepreneurs can choose how to invest in time again: back in business, share it with family, and keep it valuable for herself so they can look at IT as their ultimate ally for business and personal development.
\end{abstract}

Keywords: Stereotypes, New media, Time management, Diversity, Technology, Tips, Internet, Business

\section{Background}

\section{Greek women entrepreneurs' driving factors}

As per international survey of 2009 , Greece is rated rather high in contribution of entrepreneurs in financial life. Looking at percentages, the related gender rate is $15.51 \%$ for women entrepreneurs to $22.56 \%$ for men entrepreneurs. On the contrary, in the unemployment rate, about $22 \%$ of the female workers are unemployed vs. $15 \%$ of men

(c) 2013 Vassilakopoulou; licensee Springer. This is an Open Access article distributed under the terms of the Creative Commons Attribution License (http://creativecommons.org/licenses/by/2.0), which permits unrestricted use, distribution, and reproduction in any medium, provided the original work is properly cited. 
workers (2010). Studies have shown that usually women start their business not out of sheer opportunity but mainly driven by financial need or as a second or third profession. Many of them have experienced a considerable amount of dissatisfaction with their previous careers working for others, difficulty in combining professional and family life, and lately, loss of job. The above-mentioned parameters often force them to become their own bosses, motivating them to pursue entrepreneurship. Unfortunately, they usually tend to be micro-entrepreneurs, i.e., handle the tiny business usually run from their homes.

Once becoming business owners, women usually tend to be more satisfied and content with their personal and professional life. In addition, because of their previous careers, early retirement, etc., women entrepreneurs enter the business world later on in life, around 40 to 60 years old. Most of them have high educational degrees. Even considering that as of early 1990s, more young women are qualified to enter Universities than young men.

\section{Discussion}

\section{Women experience a 'work/life blend'}

Most women who own their own business run a busy and complex life. The holy grail of 'work/life balance' is an everyday pursuit. It is very challenging to define the balance in a uniform way, especially because those women micro-businesses are run from home. Inevitably, work and personal life get blended. So, one would say that instead of a 'work/life balance,' realistically, it is a 'work/life blend'.

To those of us who already have the experience of working from home, we already know that it is not possible to distinguish between personal and professional life. In any case, some rules should be placed in order to assist women micro-entrepreneurs in distinguishing between the two faces of the same coin. Besides, the sense of entrepreneurship leads to total and seamless obsession for one's dream; otherwise, this cannot be fulfilled. Most importantly, when a woman needs to get the business going, and is starting to earn some money, as a quick win - a sign of encouragement - the solo entrepreneur may find herself working nonstop from 5 a.m. to 11 p.m. even during mealtime or bedtime. The inevitable result would be a woman torn apart, i.e., a sister, a wife or a mother with no sense of satisfaction, no self-respect, and lots of worries and dilemmas.

To make things even worse, men entrepreneurs usually tend to extend their business hours blending them with social and sporting activities. So, evidently, women should also network in order to grasp opportunities and promote their business.

\section{The gender gap for technology - gap of role models}

Despite the contemporary success of young women with University degrees, there is a global, distinct gap between Human and Technology studies.

To bridge this parity, European Commission recently launched a campaign in order to promote increased participation of women and to reduce the gender gap, within the science, technology, engineering, and math fields. Women in other professions such as medicine and law have become fixtures on television and in movies of recent decades, while portrayals of programmers still tend to follow the hacker stereotype of the lone guy sitting in his basement. 
A $78.5 \%$ of first-year students said that they regularly used computers before attending college. The figures for women and men were $77.8 \%$ and $79.5 \%$, respectively, but women spent far less time on the internet. They were half as likely as men to rate their computer skills as above average and were five times less likely to pursue careers in computer programming - $9.3 \%$ of men as opposed to $1.8 \%$ of women - according to a survey conducted by the University of California, Los Angeles. "Research has shown that women feel that computers and technology are male domains", as per research principle.

Lack of role models both in popular culture and in day-to-day life is a key reason for the parity. So, the reason why there are less women computer scientists is simply because there are less women computer scientists, a vicious circle difficult to penetrate. It is very interesting that young women who excel in technology fields are usually brought up in a relevant family environment, i.e., scientist parents.

Specifically for computer use and digital technology, there is a very apparent sign of it: although the use of internet rises year over year, there is a steady gap of approximately $10 \%$ between women and men computer use. So, we may safely extrapolate that since women are less passionate users of the internet, it is obvious that their general use of the internet and computer literacy overall is limited. Thus, one could easily assume that women entrepreneurs and solo entrepreneurs may equally be cautious with the use of internet, technology, and digital gadgets.

\section{What has shaped our business interests}

Another aspect of how women entrepreneurs treat technology depends mainly on their generation. A very interesting recent research, performed by AUEB professors E. Nikandrou and Panagiotopoulou is entitled 'Comparing attitudes of women towards career'. The key factors that have mainly influenced generations in Greece according to the survey are the following (Figure 1):

Baby boomers generation: dictatorship 1974, Chernobyl, environment, Berlin wall, AIDS Generation X: globalization, computer, mobile, internet

Generation Y: internet, mobile, NY towers, terrorism

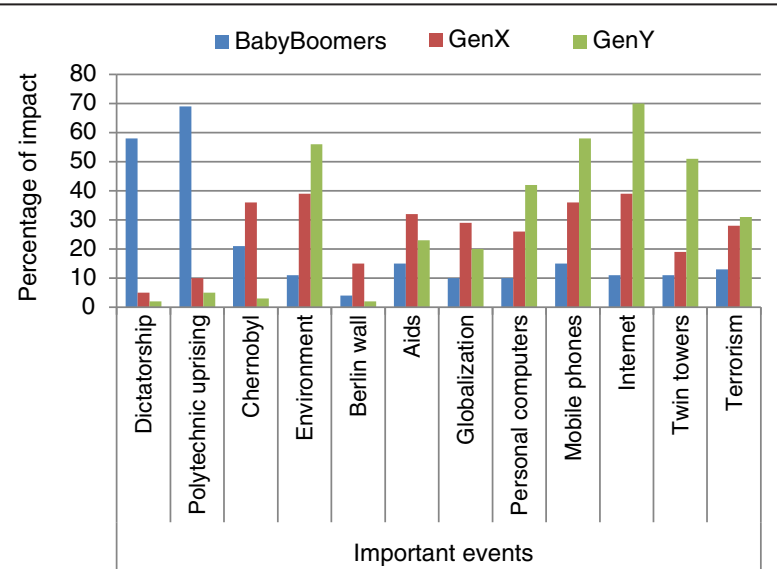

Figure 1 Percentages of impact of baby boomers generation and Generations $\mathrm{X}$ and $\mathrm{Y}$ in different important events. (Source: Nikandrou and Panagiotopoulou 2011). 
It is clear that Generations $\mathrm{X}$ and $\mathrm{Y}$, active now as entrepreneurs, have been strongly influenced by technology trends.

\section{Modern women in making business with technology}

Despite the international findings, the same as the above survey shows that women of Generations X and Y seem to have adapted and enjoyed technology (Table 1).

This is a clear sign that the younger Greek ladies are more open to set bridges with technology and use it as a required tool. The point is how technology could influence them in order to make a broader and more relaxed use. Thus, women entrepreneurs could more easily control costs, save time, keep in contact, and be flexible with their work/life blend.

Because of this significant role that technology plays in Generations X and Y, business life of those age groups seems more familiar with technology. However, looking at the age group above 45 years, these have not been brought up with tech-gadgets. It is rather rare and difficult to play in confidence with all new offerings available around.

European Union addresses the need for computer skills as critical for all citizens and classifies access to fast computer networks as a priority. The widely used term computer literacy underlines that basic computer skills are required for all, as basic skills as reading and writing.

Computer literacy is defined as the knowledge and ability to use computers and related technology efficiently, with a range of skills covering levels from elementary use to programming and advanced problem solving. Computer literacy can also refer to the comfort level someone has with using computer programs and other applications that are associated with computers. Another valuable component of computer literacy is knowing how computers work and operate (Breneman and Carter 2013).

Table 1 Women during the baby boomers generation, Generation $X$, and Generation $Y$

\begin{tabular}{|c|c|c|c|}
\hline Categories & $\begin{array}{c}\text { Baby boomers generation } \\
1946 \text { to } 1965\end{array}$ & $\begin{array}{c}\text { Generation X } 1966 \\
\text { to } 1985\end{array}$ & $\begin{array}{c}\text { Generation Y } 1986 \\
\text { to } 2000\end{array}$ \\
\hline Career & Important in life cycle & Challenge & Mobility \\
\hline Leadership & Questioning/contesting & Overseeing & Respecting \\
\hline $\begin{array}{l}\text { Yearning for } \\
\text { technology }\end{array}$ & Ruling & Enjoying & Using/applying \\
\hline Future & Creating for tomorrow & Unsure/pessimistic & Optimistic \\
\hline $\begin{array}{l}\text { Evaluation/ } \\
\text { feedback }\end{array}$ & Formal/documented & Continuous/non-formal & Non-formal, on demand \\
\hline $\begin{array}{l}\text { Inducement/ } \\
\text { motivation }\end{array}$ & $\begin{array}{c}\text { Acknowledging participation } \\
\text { and merit }\end{array}$ & $\begin{array}{l}\text { Loose adherence to norms/ } \\
\text { independence/individualism }\end{array}$ & Team-work, collaboration \\
\hline $\begin{array}{l}\text { Professional } \\
\text { virtues }\end{array}$ & $\begin{array}{c}\text { Willing to serve, communicate, } \\
\text { provide extra outcomes }\end{array}$ & $\begin{array}{l}\text { Adaptive/knowledge of } \\
\text { technology/non-conformist }\end{array}$ & $\begin{array}{l}\text { Collective action, insistence, } \\
\text { technological specialization, } \\
\text { competent }\end{array}$ \\
\hline $\begin{array}{l}\text { Professional } \\
\text { weaknesses }\end{array}$ & $\begin{array}{l}\text { Bureaucratic/difficulties in } \\
\text { managing conflicts/Intolerant } \\
\text { to different views }\end{array}$ & $\begin{array}{l}\text { Anxious/lack } \\
\text { of communication } \\
\text { skills/cynical }\end{array}$ & $\begin{array}{l}\text { In need of supervision and } \\
\text { managing, no experience in } \\
\text { interpersonal relationships }\end{array}$ \\
\hline $\begin{array}{l}\text { Work/personal } \\
\text { life balance }\end{array}$ & 'Workaholics'/living to work & $\begin{array}{l}\text { Balancing work } \\
\text { and personal life }\end{array}$ & $\begin{array}{l}\text { Flexible working hours/ } \\
\text { predominance of personal life/ } \\
\text { 'work is not everything' }\end{array}$ \\
\hline
\end{tabular}

Source: Nikandrou and Panagiotopoulou 2012. 


\section{Do it like a ...LadybizIT!}

So what are the basic functionalities that Ladybiz should acquire as basic levers of computer literacy? In interacting with many Greek lady entrepreneurs and executives, here are what they have pointed out as common main minima of knowledge and skills:

a. Progress with your English skills

Undoubtedly, the language for computers and internet is English, not the Shakespearian version of it but just simple and straightforward. Even 2,000 to 3,000 words can suffice for a first-hand survival with computer and internet. So, if you feel weak and not comfortable, make some lessons as a start.

b. A laptop is a personal tool ...

...like your toothbrush: usually, you do not share it! Embrace this piece of equipment and make yourself comfortable with it, the same way one should personalize her desk, or her room. Nice wallpaper with a family picture of the sunset of your vacation can inspire you in tough times. Choose the letter style font and size - that pleases your eyes only. Then, be happy and relaxed when these letters blow messages easily to read for you. Keep your desktop tidy, clean, precise, and rich, and make it as your real desktop. In other words, customize it. The same principles can apply to your $3 \mathrm{G}$ mobile phones.

c. Learn how to search efficiently The internet has a vast source of information for every kind of knowledge. So, learn how to select some keywords and make almost a 'human-like question'. Once your English gets stronger, you will be able to search deeper within English texts. This extends your view to business opportunities practically everywhere. In addition, mastering techniques like opening links in new windows, using bookmarks, editing URLs to perform navigation, clearing the browser cache, and understanding common error messages will give you access to a world of unlimited information.

d. Write well, calculate accurately, and present nicely Word processing is the oldest application on commercial personal computers. No one wonders how easily typewriters were replaced. Learning how to use basic functions of word processing, like spell check, table creation, and working with headers one can apply also in email and a lot of other applications.

Also, the fundamental use of spreadsheets can help us do accounting and other repetitive calculations with confidence and speed. Use of formulas, references, and macros can turn a 'grid of numbers' into actionable information in the hands of the right person.

Last but not the least, make a presentation template with your logo on it, such as on your business card! Use it in order to communicate any structured and wellorganized messages; do not allow information to leave you without your personal business touch.

e. Privacy and security first

Security becomes an increasingly important issue. It relates to two main concepts: computer security and privacy. Most of the hardware- and computer-related securities are automated provided that the user refreshes a license annually from a well-known security application. This can check the computer for nasty bugs, 
spyware, and other malicious applications. Nevertheless keep your computer personal so no other party or person, intentionally or not, can spill over harmful applications. Remember, keep your personal data private and make 'backups'. Content security and access to misfit articles, publications, and videos are other very critical aspects that especially parents should have the basic capabilities to control.

f. Basic terminology - basic commands

Knowing some hardware terminology is a must-have skill to be a savvy user. Besides, it is practically tough to have someone helping you out all of the time. Also, learning some commands like 'copy paste' is more a matter of routine than anything else; a short tutorial done once a day for a week will probably be enough to put you in the habit, and it will make you a happier, self-confident user.

g. Basic networking skills lead to endless communication Internet cannot be provided unless your computer is "connected" to a physical network. So it is important to distinguish some devises like modem, cable vs. wireless connection, IP address, hotspot name etc. It is easier than a complex cuisine recipe, provided that you ask the right person or look the manual with decisiveness and confidence.

h. Social media are business media

All LadybizIT recognized that social media do not concern only kids and teenagers. They even exceed the need to share party pictures with friends. Social media is no more a choice for business. You can easily get to a Facebook page of your product of choice (a yogurt, a soap, a magazine) and see what a powerful tool can be in the hands of marketers. Try to understand and use it in order to promote your business. Specialists in online marketing can be available to assist in this trip to an absolutely new land of 'online interaction with every single customer'.

\section{Tips to become a LadybizlT}

How can business women network, promote, stay cool, and play a positive role model for their surroundings, without often leaving their home/business territory? How could they extend or duplicate time and meeting opportunities? After all, is it worthwhile for a woman to run a business more than $12 \mathrm{~h}$ a day?

Here are some rules to keep women entrepreneurs comfortable and their stress under control in a 'work/life-blended style'. In these rules, technology has a significant role to play.

1. Use tools, adopt technology

Ask your children or other younger members of your entourage to give you some tips, hinds. Let them guide you. Show your sense of humor with the difficulties.

This will improve your interpersonal communication. Also ask your bank to enlighten you with the world of e-banking and your most capable friends with the best experience of e-tailing, ticket services, or simple troubleshooting in searches. In other words, there is no way to cherish the goods of technology available to us, unless you adopt it with your heart. In return, technology pays back, has no discriminations, and promotes your ideas as fresh and vivid as you only can produce them. 
2. Set zones - keep promises

You may not be able to turn off your computer at 5 o'clock, but you should set rules for yourself about when you work. If you work out of your home, it is even harder to resist checking your email or 3G mobile even on a sleepy Sunday, but do. Strive to separate work time and family time by closing the door to your office space, respect the 7 to 9 p.m. zone with children, or place your yoga class at your computer scheduler, so no meeting pops up at the inappropriate time. Participate in a blog with other professionals on time management, and read others' ideas that seem applicable to your lifestyle.

3. Share your expectations, make allies

It is better that you share with your close family members your dreams and your targets. Improve verbal communication with your dears. Ask them if they agree with your dreams to support you. Then, you can easily ask them for some favors or backups. If you do so, then digital communication, SMS, Viber, and Skype, can improve the coordination for day-to-day needs without widening the gap. For example, why not create a Facebook group for school and through it share children commuting with neighbors and friends.

Activate your mobile alerts - reminders that can save you time and give you the sense of control you need.

4. Occasionally...take a real break

Small business owners, especially moms, are often reluctant to take vacations, but those that do feel better go for it. Even if you believe you are indispensable at work and at home, find a way to have someone else taking over your duties for short breaks, a person willing to support you even on a swap basis. Still, you will have to communicate with this person, but it is easier with one instead of answering your emails all time. Be sure that your spouse, and/or your family will be closer to you after a constructive common interval. Even if you are alone, a better self can be much more creative and productive after a real break.

\section{Conclusion}

Women entrepreneurs have become a strong driving force in today's economy. They usually are experienced, qualified, and well educated. Their primary goal is not only monetary reward but rather personal satisfaction. Yet, despite the forces and opportunities, many prospective women entrepreneurs are intimidated to move out of their comfort zone. Unfortunately, between other competencies, technology is still out of women entrepreneurs' comfort zone. So, for these women, it is advisable to adopt LadybizIT as role models and get inspired by them. They should get motivated by surrounding female business networks, such as Togme or other long lasting clubs where successful trends are shared openly. Women should plan their transition towards information technology and mobility, asking as guides even their kids or other young willing family members with open eyes and sheer eagerness to communicate. Last but not least, women entrepreneurs should evaluate how to rely extensively on social media, mobility, and e-commerce, as they can offer them global, diverse, and inclusive fields for their business ideas. 
Acknowledgements

The author wishes to thank Militos Emerging Technologies \& Services and Kyriakos Lingas.

Received: 2 December 2012 Accepted: 7 May 2013

Published: 21 May 2013

\section{References}

Breneman, C, \& Carter, C (Eds.). (2013). Computer literacy. http://www.wikipedia.com.

Nikandrou, E, \& Panagiotopoulou, L. (2011). Comparing attitude of women towards career. Athens: Athens University of Economics and Business.

Nikandrou, E, \& Panagiotopoulou, L. (2012). Career and Generation Y. Athens: Athens University of Economics and Business.

doi:10.1186/2192-5372-2-3

Cite this article as: Vassilakopoulou: The contribution of technology in business growth: the case of Greek ladies. Journal of Innovation and Entrepreneurship 2013 2:3.

\section{Submit your manuscript to a SpringerOpen ${ }^{\circ}$ journal and benefit from:}

- Convenient online submission

Rigorous peer review

- Immediate publication on acceptance

- Open access: articles freely available online

High visibility within the field

- Retaining the copyright to your article

Submit your next manuscript at $\boldsymbol{\sim}$ springeropen.com 